\title{
Spatial and Seasonal Characterization of Water Quality in The Ouémé River Basin (Republic of Benin, West Africa)
}

\author{
A.M. Houssou $^{1 *}$, S. Ahouansou Montcho ${ }^{1,2}$, E. Montchowui ${ }^{1,2}$, C.A. Bonou ${ }^{3}$ \\ ${ }^{1}$ Laboratoire de Recherche en Aquaculture et en Biologie et Ecologie Aquatiques, \\ Ecole d'Aquaculture de la vallée, Université Nationale d'Agriculture, Porto Novo, \\ Bénin \\ ${ }^{2}$ Laboratoire d'Hydrobiologie et d'Aquaculture, Faculté des Sciences Agronomiques, \\ Université d'Abomey-Calavi, Bénin \\ ${ }^{3}$ Laboratoire de Recherche en Biologie Appliquée, Ecole Polytechnique d'Abomey- \\ Calavi, Université d'Abomey-Calavi, Bénin
}

\begin{abstract}
$\mathbf{T}$ HE STUDY aims at evaluating the quality of the water in the Ouémé River basin. Data were collected from October 2014 through September 2015. Physico-chemical parameters were assessed and the concentrations of dissolved heavy metals were determined. The results show both physical and chemical pollutions of the water according to a nonlinear pollution gradient. The middle basin up to the height of the city of Kaboua appears to be the most polluted segment. The Delta region, near the coast, is the second most polluted segment, and the remaining parts of the basin are the least polluted. Pollutant concentrations are highest during the low flow season. Cluster analysis and Principal Component Analysis (PCA) of sampled sites reveals that Atchakpa-Rejet and Kaboua have high concentrations of nitrite, nitrate, ammonium, orthophosphate, conductivity, TDS, pH, calcium, magnesium, and total hardness. Kpassa, Bétérou, and Atchakpa-Bethel have high dissolved oxygen and high transparency values. All other sites have high alkalinity. During the low flow season, $\mathrm{Cd}, \mathrm{Pb}, \mathrm{Zn}$ and $\mathrm{Cu}$ were detected at concentrations exceeding ecological standards in most of the sites. The Water Quality Index (WQI) ranged from 52.7 to 80.9 , meaning that water in that river basin can be classified either as marginal quality, moderately polluted, or good quality for aquatic life. Overall, water in the Oueme River basin is under high and increasing influence of human activities.
\end{abstract}

Keywords: Aquatic life, Anthropization; Excessive mineralization, Heavy metals, Household.

\section{Introduction}

Assessment of water quality can be defined as the analysis of physical, chemical and biological characteristics of water [1]. To allow people to derive the most benefit from this resource, monitoring the quality of surface water has become a recurrent practice worldwide. It then becomes possible to establish the first indicators of the health status of an aquatic ecosystem through the determination of physical and chemical parameters. Collecting and analyzing these parameters is important as this serves as a basis for developing a set of inclusive management strategies (some of which can be complex) which will favor the continued existence of aquatic life in the river. These parameters are likely to continually change over time due to sustained human activity in the basin $[2,3,4,5]$. As a result, it is important to continually monitor them. Mustapha [6] has argued that changes in physical (temperature, transparency) and chemical characteristics of water (dissolved oxygen, chemical oxygen demand, nitrate, phosphate, $\mathrm{pH}$, conductivity, total dissolved solids, total alkalinity, total hardness, calcium, magnesium, silica, sulphate, carbon dioxide) provide valuable information about the quality of the said water, the source of the observed variations, and their impact on both the function and biodiversity of the ecosystem.

Indeed, surface water that is contaminated by household and agricultural effluents as well

* Corresponding author: arsnehous@yahoo.fr

DOI: 10.21608/ejchem.2017.1463.1095

C2017 National Information and Documentation Centre (NIDOC) 
as industrial pollutants can undergo such quality change that its quality will negatively affect all components of the ecosystem. In fact, it is known that polluted water has a negative impact on the chemical makeup of the aquatic life living therein and can have deleterious effects on humans feeding on those organisms, bathing in such water, or using it for drinking, which is the case of the inhabitants of the Ouémé river basin.

Throughout the basin, riverine people use water from the basin for all their needs (drinking, cooking, bathing, laundry, etc.) without any prior treatment. The risk of intoxication is therefore always permanent in view of the high pollution of this water. Agricultural production is sadly an important source of pollution, followed by industry. The industrial pollution in this case is due to a sugar-making company, the Sucrerie $d u$ Complant du Bénin (SUCOBE), which causes considerable pollution at the latitude of Atchakpa. This pollution affects the fish fauna in the area and disrupts the phytoplankton and zooplankton structure [7]. The increasing urbanization in the basin, especially in the lower part, also contributes high pollution to the water system as a result of household effluents, which is an important source of pollutants for both groundwater and surface water $[8,9]$. Taken together, the water in this basin is negatively impacted by household effluents, industrial discharges, and agricultural pollutants. The anthropization is taking place over a large portion of the basin; that's why it is important to regularly monitor the evolution of this situation through abiotic parameters. As a result, the goal of this study is to evaluate the longitudinal and temporal distribution of the physico-chemical parameters in the Ouémé River basin.

\section{Material and Methods}

Study area

The Ouémé River basin is the largest catchment area $\left(50.000 \mathrm{~km}^{2}\right)$ in the Republic of Benin. It makes up nearly half of the area of the country. Its watershed lies between $6^{\circ} 51^{\prime}$ and $10^{\circ} 11^{\prime} \mathrm{N}$ and $1^{\circ} 29^{\prime}$ and $3^{\circ} 24^{\prime} \mathrm{E}$. The Ouémé River, which drains the basin, is the longest river $(510 \mathrm{~km})$ in Benin. Its main tributaries are the Okpara (362 km), Zou (250 km), Beffa (78 km), and Donga Rivers $(74 \mathrm{~km})$. In Benin, rainfall is the main element generating differences in the climate [10]. The Ouémé basin has three climatic zones, namely 1) the dry Sudanian zone, between the $9^{\circ} \mathrm{N}$ and $12^{\circ} \mathrm{N}$, where rainfall varies from 900 to $1100 \mathrm{~mm}$ per year; 2) the Sudano-Guinean Egypt. J. Chem. 60, No. 6 (2017) zone, between the $8^{\circ} \mathrm{N}$ and $9^{\circ} \mathrm{N}$, where rainfall varies from 1000 to $1200 \mathrm{~mm}$ per year; and 3) the Subequatorial zone, between the Atlantic coast $\left(6^{\circ} 21^{\prime} \mathrm{N}\right)$ to the latitude of the town of Savè $\left(7^{\circ} 30^{\prime} \mathrm{N}\right)$, where rainfall varies from 950 to 1400 $\mathrm{mm}$ per year [11]. The hydrological regime is of a tropical transition type. There is a strong interannual and spatial irregularity of the water flow in the basin. Floods occur in the basin roughly from August to November.

The pollution sources in Ouémé River basin are restricted to household and agricultural effluents throughout the basin. Only a sugarmaking company (the Sucrerie du Complant du Bénin (SUCOBE) located at Atchakpa contribute as industrial pollution by discharging wastewater in the River. So, occurring of pollution in Ouémé river basin might be mainly dependent of agriculture (intensive production of cotton and of food crops) and household (high urbanization of many sites and absence of water treatment plant).The distribution of these pollution sources according to sampling sites, is shown in table 1 .

\section{Sampling sites}

In this study, samples were collected at 15 stations (cf. figure 1, Table 1). Nine stations (Affon, Bétérou, Atchakpa-Béthel, Atchakpa-Rjet, Atchakpa-Pumping, Bétékoukou, Zagnanado, Bonou and Agonlin-lowé) are located on the main river. Stations Affon, Bétérou, AtchakpaBéthel, Atchakpa-Rejet and Atchakpa-Pumping were chosen to represent the upper reaches of the river. Atchakpa-Rejet refers to the wastewater discharge point of the sugar-making company on Ouémé River, while Atchakpa-Pumping refers to the water pumping station of the company. The three Atchakpa stations will allow evaluating the impacts of the sugar plant on the river's water. The lower reaches were covered by the Bétékoukou, Zagnanado, Bonou and Agonlin-lowé stations; Agonlin-lowé and Bonou being located in the river's delta.

As far as the tributaries are concerned, six stations (Kpassa hydraulic dam, Kaboua, Toué, Atchérigbé, Vossa and Donga) were identified. The Kpassa hydraulic dam and the Kaboua station are on the Okpara River; Toué and Atchérigbé are on the Zou River, while Vossa and Donga are on the Beffa Donga Rivers. 
TABLE1. Geographic coordinates of sampling sites and pollution sources.

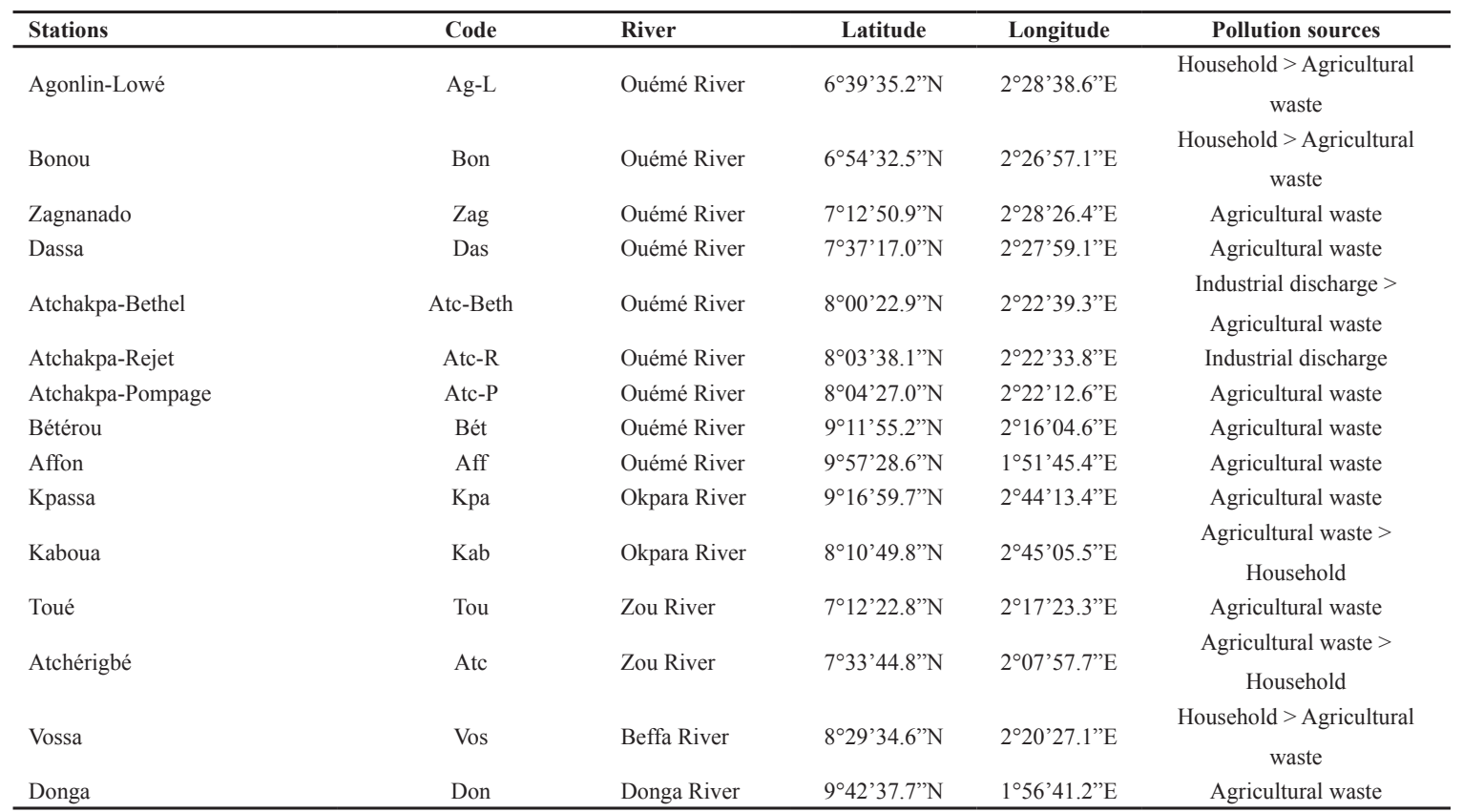

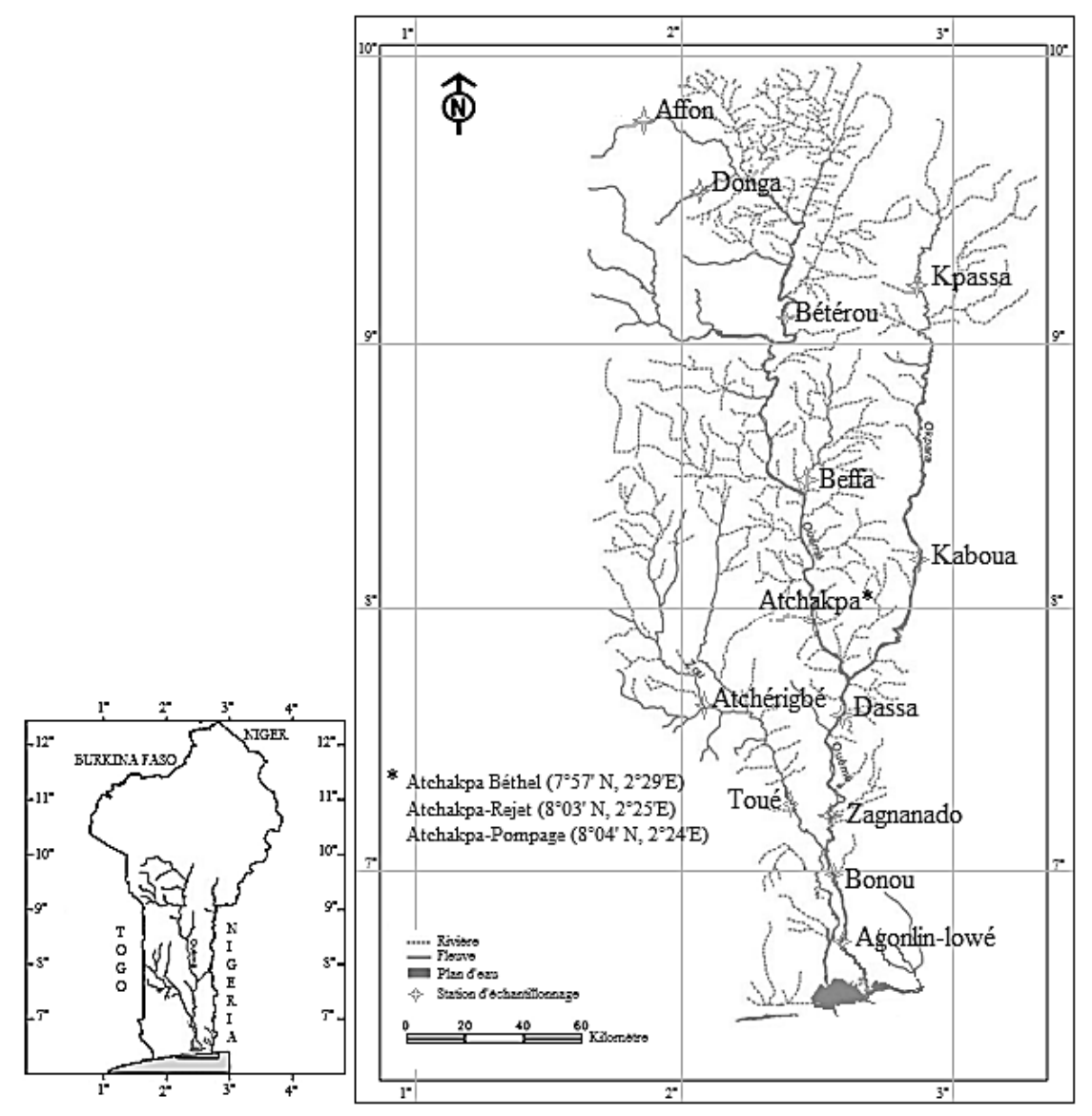

Fig. 1. Location of sampling sites.

Egypt. J. Chem. 60, No. 6 (2017) 
Physical and chemical parameters assessment

Physico-chemical parameters such as temperature $\mathrm{pH}$, dissolved oxygen, electrical conductivity, total dissolved solids (TDS), and water transparency were measured in-situ. Each of these parameters was measured monthly, from October 2014 to September 2015, on each of the 15 stations. Measurements were made at a depth located between 15 and $30 \mathrm{~cm}$, depending on whether the station is deep $(\geq 30 \mathrm{~cm})$ or shallow $(\leq 30 \mathrm{~cm})$. A Hanna multi-parameter electronic probe (HI 9813-6), a Hanna oximeter (HI 9146), and a Secchi disk were used. All measurements were made between 07:00 am and 10:00 am.

For the determination of salt concentrations, water samples were taken each month at each site between 15 and $30 \mathrm{~cm}$ of depth using a horizontal Van Dorn sampler (capacity $=2 \mathrm{~L}$ ). From this sample, a $500 \mathrm{ml}$ aliquot was taken after homogenization, was filtered with a GF/C filter, and was transferred to a plastic bottle. This sample was immediately cold-conditioned until the parameters ware analyzed. Parameters such as $\mathrm{PO}_{4}-, \mathrm{NO}_{3}-, \mathrm{NO}_{2}-, \mathrm{NH}_{4}^{+}, \mathrm{Ca}_{2}+, \mathrm{Mg}_{2}+$ total alkalinity and total hardness were determined using standards methods [12].

Regarding heavy metals concentrations, they were assessed twice during low flow (February and March) and twice during flood (September and October). The Van Dorn sampler was used to collect $2 \mathrm{~L}$ surface water from which $500 \mathrm{ml}$ were derived for the determination of heavy metals concentrations. This collected water was filtered within 24 hours over a Whatman filter membrane of $0.45 \mu \mathrm{m}$ mesh size and was then stored in polyethylene bottle which was initially washed with detergent and a mixture of dilute nitric and hydrochloric acid. It was then acidified with nitric acid to a $\mathrm{pH}$ of less than 2 . This sample was stored at $4^{\circ} \mathrm{C}$ until dissolved metals analysis (cadmium, lead, zinc and copper). Dissolved heavy metals content was quantified using flame atomic absorption spectrophotometry (SAAF) method [12].

Data analysis

Descriptive statistical analysis was done for each parameter to study their variability from station to station and between hydrological seasons. To test the variability of the mean values of the parameters between several stations, Kruskal-Wallis test was used. The Mann-Whitney test was used to highlight difference between seasons [13]. A Cluster analysis of sampling sites was done to study similarity between the stations. This analysis was followed by a Principal Component Analysis (PCA) to categorize and characterize the sampling sites.

To characterize the pollution level of the stations for aquatic life, the water quality index of the Canadian Council of Ministers of the Environment (CCME-WQI) was calculated. The water quality standards used in this calculation are presented in table 2 . The index was calculated according to CCME [46].

TABLE 2. Quality standards for physico-chemical parameters and dissolved metals used in the CCME-WQI calculation.

\begin{tabular}{|c|c|c|}
\hline \multirow[t]{2}{*}{ Parameters } & \multicolumn{2}{|c|}{ Aquatic life standards } \\
\hline & Standards & Sources \\
\hline $\mathrm{pH}$ & $6.5-8.5$ & IBGE (2005) \\
\hline Conductivity $(\mu \mathrm{S} / \mathrm{cm})$ & $50-1500$ & IBGE (2006) \\
\hline $\mathrm{DO}(\mathrm{mg} / \mathrm{L})$ & $>4$ & IBGE (2008) \\
\hline $\mathrm{NH}_{4}+(\mathrm{mg} / \mathrm{L})$ & $<2 \mathrm{mg} / 1 \mathrm{~N}$ & Bruxelles Environnement (2011) \\
\hline $\mathrm{NO}_{3}-(\mathrm{mg} / \mathrm{L})$ & $<100$ & Morin (2012) \\
\hline $\mathrm{NO}_{2}-(\mathrm{mg} / \mathrm{L})$ & $<0.1 \mathrm{mg}$ & Morin (2012) \\
\hline $\mathrm{PO}_{3}-(\mathrm{mg} / \mathrm{L})$ & $<0.15 \mathrm{mg} / 1$ & Bruxelles Environnement (2011) \\
\hline Total hardness (mg/L de CaCO3) & $10-500$ & Morin (2012) \\
\hline Alkalinity $(\mathrm{mg} / \mathrm{L})$ & $20-400$ & Morin (2012) \\
\hline $\operatorname{Zinc}(\mu \mathrm{g} / \mathrm{L})$ & $7.8 \mu \mathrm{g} / \mathrm{L}$ & MEEM (2016) \\
\hline Copper $(\mu \mathrm{g} / \mathrm{L})$ & $\begin{aligned} & 1 \mu \mathrm{g} / \mathrm{L} \\
\leq & 0.45(\mathrm{C} 1)\end{aligned}$ & MEEM (2016) \\
\hline \multirow{3}{*}{ Cadmium $(\mu \mathrm{g} / \mathrm{L})$} & $0.45(\mathrm{C} 2)$ & \multirow{3}{*}{ MEEM (2016) } \\
\hline & $0.6(\mathrm{C} 3)$ & \\
\hline & $0.9(\mathrm{C} 4)$ & \\
\hline Lead $(\mu \mathrm{g} / \mathrm{L})$ & 14 & MEEM (2016) \\
\hline
\end{tabular}

$\mathrm{C} 1$ : Hardness class $\leq 40 \mathrm{mg} / \mathrm{L} ; \mathrm{C} 2$ : hardness between 40 and $50 \mathrm{mg} / \mathrm{L} ; \mathrm{C} 3$ : hardness between 50 and $100 \mathrm{mg} / \mathrm{L} ; \mathrm{C} 4$ : hardness between 100 and $200 \mathrm{mg} / \mathrm{L}$.

Egypt. J. Chem. 60, No. 6 (2017) 


\section{Results}

Spatial variability of environmental parameters

The variability of the physico-chemical parameters between the investigated sites is represented in figure 2. Temperature, dissolved oxygen, calcium, magnesium, total hardness, total alkalinity, ammonium, and nitrate values are not significantly different from site to site ( $\mathrm{p}$ $>0.05)$. The mean values are located between 27.53 and $27.9^{\circ} \mathrm{C}$ for temperature, 4.2 and 5.7 mg. $\mathrm{L}^{-1}$ for dissolved oxygen, 5.7 and $14.1 \mathrm{mg} . \mathrm{L}^{-1}$ for calcium, 3.6 and $6.3 \mathrm{mg} . \mathrm{L}^{-1}$ for magnesium, and 29.01 and $60.29 \mathrm{mg} . \mathrm{L}^{-1}$ for total hardness. As for total alkalinity, the mean values are between 82.54 and $149.88 \mathrm{mg} . \mathrm{L}^{-1}$; for ammonium and nitrate, mean values ranged from 0.3 to $5.6 \mathrm{mg} . \mathrm{L}^{-1}$ and from 5.9 to $42.6 \mathrm{mg} . \mathrm{L}^{-1}$, respectively.

The mean $\mathrm{pH}$, conductivity, TDS, transparency, nitrite, and orthophosphate values are significantly different from site to site $(\mathrm{p}<0.05)$. The lowest $\mathrm{pH}$ is observed at Zagnanado (with a mean $\mathrm{pH}$ of 7) whereas $\mathrm{pH}$ at Atchakpa-Rejet and Kaboua stations is basic (with means of 8.2 and 8.4, respectively). The lowest mean values (816.7 $\mu{\mathrm{S} . \mathrm{cm}^{-1}}^{-1}$ and $65.7 \mathrm{mg} . \mathrm{L}^{-1}$, respectively) for conductivity and TDS are at Dassa, while the highest mean values (1816.7 $\mu$ S.cm ${ }^{-1}$ and 138 mg. $\mathrm{L}^{-1}$, respectively) are recorded at Kaboua and the highest values $\left(4700 \mu \mathrm{S} . \mathrm{cm}^{-1}\right.$ and $335 \mathrm{mg} . \mathrm{L}$ ${ }^{1}$, respectively) are recorded at Kaboua as well. Water transparency is lower at Donga with a mean of $27.3 \mathrm{~cm}$, while it is higher $(77 \mathrm{~cm})$ at AtchakpaBethel. Nitrite concentrations are generally low: the highest mean $\left(0.34 \mathrm{mg} . \mathrm{L}^{-1}\right)$ was observed at Vossa, and the lowest mean (0.003 mg.L $\left.\mathrm{L}^{-1}\right)$ was observed at Kpassa. Mean orthophosphate values varied between $0.097 \mathrm{mg} . \mathrm{L}^{-1}$ (Kpassa) and 1.51 mg. $\mathrm{L}^{-1}$ at Vossa.

In general, parameters indicating environmental degradation are highest at stations such as Kaboua, Vossa, Atchakpa-Rejet and Agonlin-lowé.

\section{Seasonal variation of physical and chemical parameters}

Variations in the various environmental parameters between flood and low flow periods in the Ouémé River basin are presented in figure 3. For those two hydrological periods, temperature, $\mathrm{pH}$, alkalinity, and ammonium are not significantly different $(p>0.05)$. Their mean values during low flow are respectively $27.7^{\circ} \mathrm{C}, 7.7,109.3 \mathrm{mg} . \mathrm{L}-$
${ }^{1}$ and $1.69 \mathrm{mg} . \mathrm{L}^{-1}$; while the respective means are $27.69^{\circ} \mathrm{C}, 7.6,126.2 \mathrm{mg} . \mathrm{L}^{-1}$, and $1.23 \mathrm{mg} . \mathrm{L}^{-1}$ during floods.

With regard to the other parameters under investigation, a significant difference was observed for each of them between the two hydrological seasons $(\mathrm{p}<0.05)$. In fact, the highest mean value for conductivity $\left(1208.3 \mu \mathrm{S} . \mathrm{cm}^{-1}\right)$, TDS (92.4 mg. $\left.\mathrm{L}^{-1}\right)$, transparency $(44.6 \mathrm{~cm})$, calcium $(9.9$ mg. $\left.\mathrm{L}^{-1}\right)$, magnesium (4.9 mg. $\left.\mathrm{L}^{-1}\right)$, nitrate (18.8 mg. $\left.\mathrm{L}^{-1}\right)$, nitrite $\left(0.08 \mathrm{mg} . \mathrm{L}^{-1}\right)$, orthophosphate (0.42 mg.L $\left.\mathrm{L}^{-1}\right)$, and total hardness (45.05 mg.L1) were recorded at low flow. The lowest mean value for conductivity $\left(790 \mu \mathrm{S} . \mathrm{cm}^{-1}\right)$, TDS $(61.8$ $\left.\mathrm{mg} . \mathrm{L}^{-1}\right)$, transparency $(35.5 \mathrm{~cm})$, calcium $(7.2$ mg. $\left.\mathrm{L}^{-1}\right)$, magnesium (4.2 mg. $\left.\mathrm{L}^{-1}\right)$, nitrate (5.4 $\left.\mathrm{mg} . \mathrm{L}^{-1}\right)$, nitrite $\left(0.016 \mathrm{mg} . \mathrm{L}^{-1}\right)$, orthophosphate (0.16 mg.L $\left.{ }^{-1}\right)$, and total hardness $\left(35.7 \mathrm{mg} . \mathrm{L}^{-1}\right)$ were recorded during floods. The higher mean dissolved oxygen value $\left(5.4 \mathrm{mg} . \mathrm{L}^{-1}\right)$ was recorded during flood, whereas its lowest mean (4.5 mg.L$\left.{ }^{1}\right)$ was observed at low flow.

It can be seen that environmental parameters in the water of the Ouémé River basin are more concentrated during the low flow season.

\section{Clustering of sampling sites}

The hierarchical classification of the investigated sites based on the physico-chemical parameters of the water (figure 4) reveals three groups (G1, G2 and G3), and Principal Component Analysis (PCA) (figure 5) links the groups to the dominant parameters. So, G1 is composed of two stations (Kaboua and Atchakpa-Rejet) and is characterized by high values of nitrite $(0.01 \mathrm{mg}$. L1 - $\left.0.99 \mathrm{mg} . \mathrm{L}^{-1}\right)$, nitrate $\left(1.58 \mathrm{mg} . \mathrm{L}^{-1}-163.36\right.$ mg.L. $\left.\mathrm{L}^{-1}\right)$, ammonium (0.2 mg.L $\left.\mathrm{L}^{-1}-9.74 \mathrm{mg} . \mathrm{L}^{-1}\right)$, orthophosphate (0.15 mg.L-1 - 2.39 mg.L-1), conductivity $(800 \mu \mathrm{S} . \mathrm{cm}-1-4700 \mu \mathrm{S} . \mathrm{cm}-1)$, TDS (65 mg.L $\mathrm{L}^{-1}-335$ mg.L $\left.\mathrm{L}^{-1}\right), \mathrm{pH}(7.8$ - 9.5), calcium (4.76 mg.L $\left.\mathrm{L}^{-1}-34.45 \mathrm{mg} . \mathrm{L}^{-1}\right)$, magnesium (2.65 mg.L $\left.\mathrm{L}^{-1}-8.86 \mathrm{mg} . \mathrm{L}^{-1}\right)$, and total hardness $(22.96$ mg.. $\left.\mathrm{L}^{-1}-123.05 \mathrm{mg} . \mathrm{L}^{-1}\right) . \mathrm{G} 2$ is composed of three stations (Kpassa, Bétérou and Atchakpa-Bethel) and is characterized by high dissolved oxygen (3.6 mg.L. $\left.\mathrm{L}^{-1}-6.7 \mathrm{mg} . \mathrm{L}^{-1}\right)$ and transparency $(37 \mathrm{~cm}$ $112 \mathrm{~cm}$ ) values. G3 is composed of ten additional stations (Vossa, Toué, Dassa, Atchérigbé, Zagnanado, Atchakpa-Pumping, Bonou, Agonlinlowé, Donga and Affon) and is characterized by high alkalinities (50 mg. $\left.\mathrm{L}^{-1}-329.99 \mathrm{mg} . \mathrm{L}^{-1}\right)$.

We find that water in stations such as Kaboua and Atchakpa-Rejet is more mineralized.

Egypt. J. Chem. 60, No. 6 (2017) 

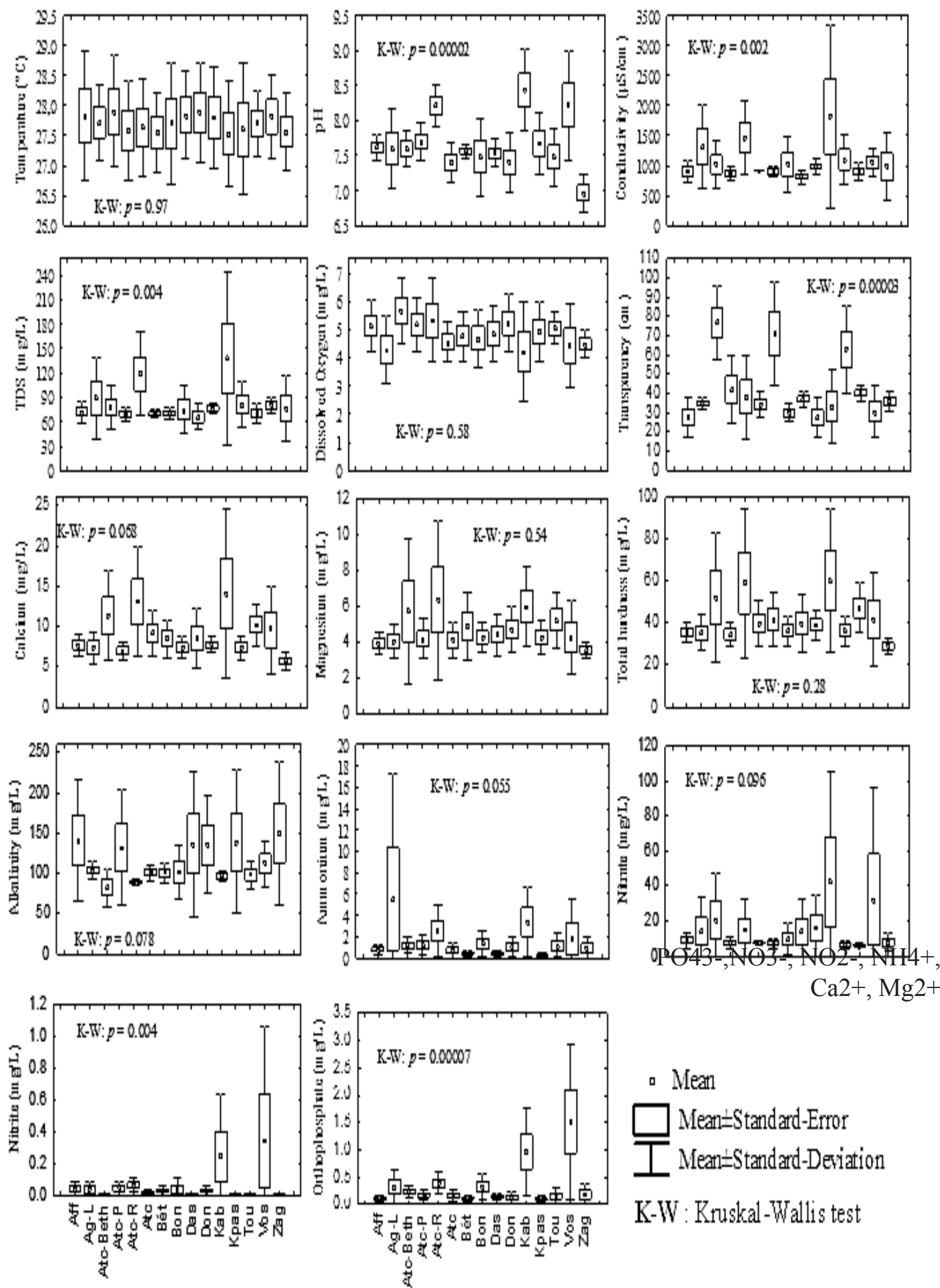

$\mathrm{Ca} 2+, \mathrm{Mg} 2+$

Fig. 2. Spatial profile of environmental parameters of water in the Ouémé River basin. The stations codes are same as in Table 1.

Egypt. J. Chem. 60, No. 6 (2017) 


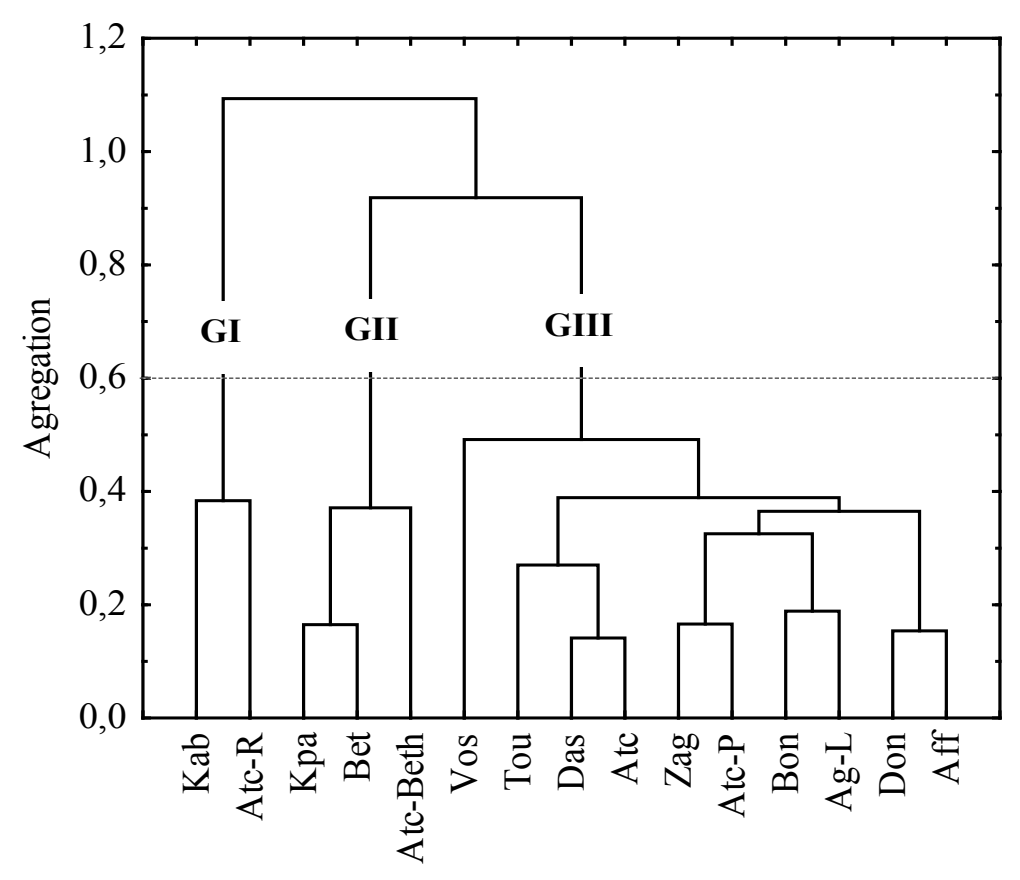

Fig. 3. Cluster analysis of sampling sites on the base of environmental parameters. The stations codes are same as in Table 1.

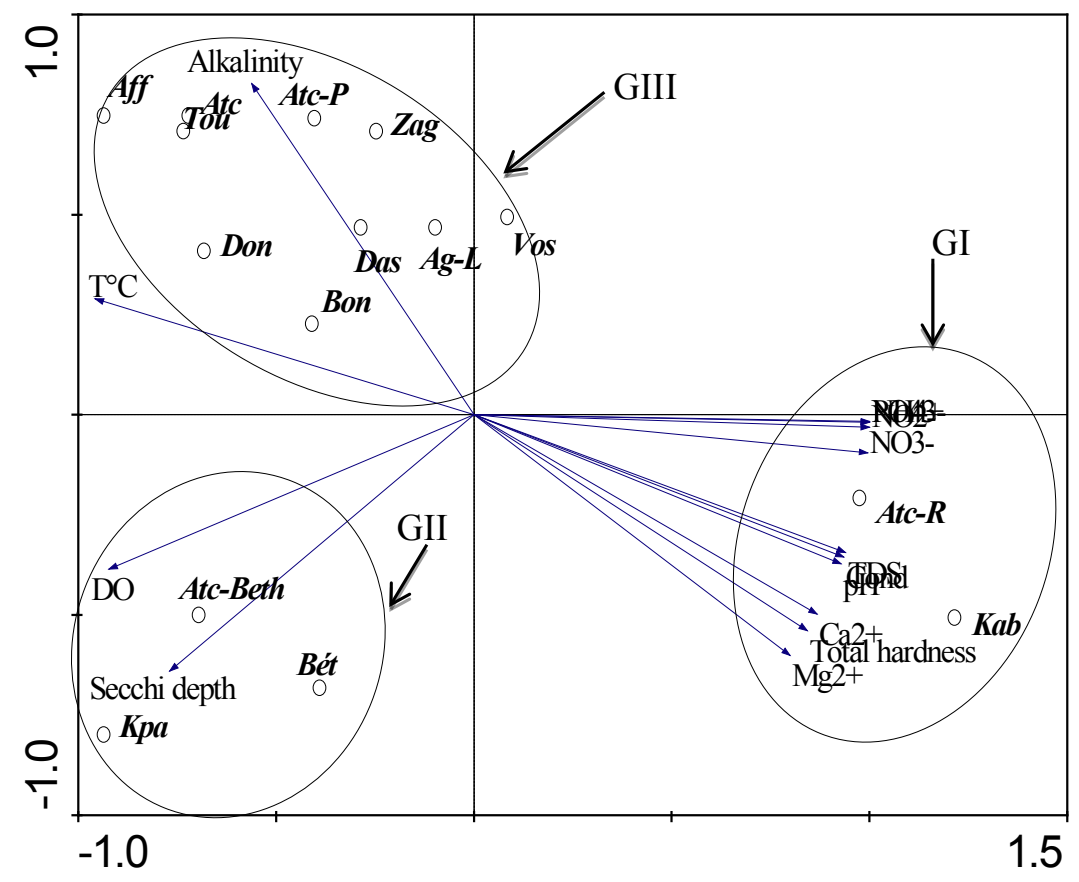

Fig. 4. Principal Component Analysis (PCA) of sampling sites based on environmental parameters. The stations codes are same as in Table 1. 
Seasonal variation of dissolved heavy metals

Cadmium was detected at three stations (Zagnanado, Dassa, and Kaboua) (cf. Table 3). The highest mean concentration $\left(0.012 \pm 0.00 \mathrm{mg}\right.$. $\mathrm{L}^{-}$ $\left.{ }^{1}\right)$ was observed during the low flow in Kaboua. During the flood, the concentration of this dissolved metal is very low at the three sites $(<0.0001 \mathrm{mg}$.L $\left.{ }^{1}\right)$. Lead was detected at most stations, except Toué, Atchérigbé, Vossa and Donga. The highest observed mean lead concentration is $0.400 \pm 0.03 \mathrm{mg} . \mathrm{L}^{-1}$ at Zagnanado, during low flow. It was followed by $0.397 \pm 0.18 \mathrm{mg} . \mathrm{L}^{-1}$ recorded in Kaboua. Zinc was not detected in any of the following three sites: Atchakpa, Kaboua, Affon. The highest zinc means were recorded at Donga $\left(0.029 \pm 0.00 \mathrm{mg} . \mathrm{L}^{-1}\right)$ and Vossa stations $\left(0.028 \pm 0.02 \mathrm{mg} . \mathrm{L}^{-1}\right)$. For copper, $0.057 \pm 0.06 \mathrm{mg} . \mathrm{L}^{-1}$ was the highest observed mean at Bonou, during low flow. However, it was not detected at any of the three sites of Atchakpa. Water in the Ouémé River basin is therefore polluted by heavy metals such as cadmium, copper, zinc, and lead which are more concentrated during low flows. Frequency of detection and concentration lays out as follows: Lead $>$ Copper $>$ Zinc $>$ Cadmium. Stations such as Dassa and Zagnanado are polluted with all of the investigated heavy metals.

\section{Variation of water quality for aquatic life}

Water quality at each station is presented in Table 4. The Quality Index values range from 52.7 to 80.9 classifying water into three categories for aquatic life. In particular, Toué enjoys good quality water (80.9), Agonlin-lowé, Bonou, Zagnanado, AtchakpaRejet, Kaboua and Vossa have a marginal quality of water (52.7 to 64.3), and the remaining stations are moderately polluted (65.7 to 79.2). Water in the Ouémé River basin is therefore of moderately poor quality for aquatic life.

TABLE 3. Mean values and standard deviation values of concentration of dissolved metals in the water of Ouémé River during the flood and low-flow.

\begin{tabular}{|c|c|c|c|c|c|}
\hline Stations & Periods & $\mathrm{Cd}(\mathrm{mg} / \mathrm{L})$ & $\mathrm{Pb}(\mathrm{mg} / \mathrm{L})$ & $\mathrm{Zn}(\mathrm{mg} / \mathrm{L})$ & $\mathrm{Cu}(\mathrm{mg} / \mathrm{L})$ \\
\hline \multirow{2}{*}{ Aglonlin-lowé } & Low-flow & $<\mathrm{Ld}$ & $0.306 \pm 0.02$ & $0.019 \pm 0.00$ & $0.013 \pm 0.00$ \\
\hline & Flood & $<\operatorname{Ld}$ & $0.109 \pm 0.05$ & $0.001 \pm 0.00$ & 0.000 \\
\hline \multirow{2}{*}{ Bonou } & Low-flow & $<\mathrm{Ld}$ & $0.293 \pm 0.04$ & $0.010 \pm 0.00$ & $0.057 \pm 0.06$ \\
\hline & Flood & $<\mathrm{Ld}$ & $0.106 \pm 0.001$ & $0.001 \pm 0.00$ & 0.000 \\
\hline \multirow{2}{*}{ Zagnanado } & Low-flow & $0.001 \pm 0.00$ & $0.400 \pm 0.03$ & $0.016 \pm 0.01$ & $0.015 \pm 0.00$ \\
\hline & Flood & 0.000 & $0.181 \pm 0.10$ & $0.003 \pm 0.00$ & $0.003 \pm 0.00$ \\
\hline \multirow{2}{*}{ Toué } & Low-flow & $<\operatorname{Ld}$ & $<\mathrm{Ld}$ & $0.005 \pm 0.00$ & $0.020 \pm 0.01$ \\
\hline & Flood & $<\mathrm{Ld}$ & $<\mathrm{Ld}$ & 0.000 & 0.000 \\
\hline \multirow{2}{*}{ Atchérigbé } & Low-flow & $<\mathrm{Ld}$ & $<\mathrm{Ld}$ & $0.008 \pm 0.00$ & $0.013 \pm 0.01$ \\
\hline & Flood & $<\mathrm{Ld}$ & $<\mathrm{Ld}$ & $0.001 \pm 0.00$ & 0.000 \\
\hline \multirow{2}{*}{ Dassa } & Low-flow & $0.003 \pm 0.00$ & $0.316 \pm 0.06$ & $0.013 \pm 0.01$ & 0.000 \\
\hline & Flood & 0,000 & $0.028 \pm 0.00$ & $<\mathrm{Ld}$ & 0.000 \\
\hline \multirow{2}{*}{ Atchakpa-Béthel } & Low-flow & $<\mathrm{Ld}$ & $0.235 \pm 0.02$ & $<\mathrm{Ld}$ & $<\mathrm{Ld}$ \\
\hline & Flood & $<\operatorname{Ld}$ & $0.081 \pm 0.01$ & $<\mathrm{Ld}$ & $<\mathrm{Ld}$ \\
\hline \multirow{2}{*}{ Atchakpa-Rejet } & Low-flow & $<\mathrm{Ld}$ & $0.363 \pm 0.08$ & $<\mathrm{Ld}$ & $<\mathrm{Ld}$ \\
\hline & Flood & $<\mathrm{Ld}$ & $0.112 \pm 0.05$ & $<\mathrm{Ld}$ & $<\mathrm{Ld}$ \\
\hline \multirow{2}{*}{ Atchakpa-Pompage } & Low-flow & $<\mathrm{Ld}$ & $0.285 \pm 0.01$ & $<\mathrm{Ld}$ & $<\mathrm{Ld}$ \\
\hline & Flood & $<\operatorname{Ld}$ & $0.117 \pm 0.04$ & $<\mathrm{Ld}$ & $<\mathrm{Ld}$ \\
\hline \multirow{2}{*}{ Kaboua } & Low-flow & $0.012 \pm 0.00$ & $0.397 \pm 0.18$ & $<\mathrm{Ld}$ & 0.000 \\
\hline & Flood & 0.000 & $0.183 \pm 0.12$ & $<\mathrm{Ld}$ & $<\mathrm{Ld}$ \\
\hline \multirow{2}{*}{ Vossa } & Low-flow & $<\mathrm{Ld}$ & $<\mathrm{Ld}$ & $0.028 \pm 0.02$ & $0.003 \pm 0.00$ \\
\hline & Flood & $<\mathrm{Ld}$ & $<\mathrm{Ld}$ & $0.001 \pm 0.00$ & $<\mathrm{Ld}$ \\
\hline \multirow{2}{*}{ Kpassa } & Low-flow & $<\mathrm{Ld}$ & 0.000 & 0.000 & $0.003 \pm 0.00$ \\
\hline & Flood & $<\mathrm{Ld}$ & 0.000 & 0.000 & 0.000 \\
\hline \multirow{2}{*}{ Bétérou } & Low-flow & $<\operatorname{Ld}$ & $0.027 \pm 0.01$ & $0.019 \pm 0.00$ & $0.004 \pm 0.00$ \\
\hline & Flood & $<\mathrm{Ld}$ & 0.000 & 0.000 & $<\mathrm{Ld}$ \\
\hline \multirow{2}{*}{ Donga } & Low-flow & $<\mathrm{Ld}$ & $<\mathrm{Ld}$ & $0.029 \pm 0.00$ & $0.020 \pm 0.00$ \\
\hline & Flood & $<\mathrm{Ld}$ & $<\mathrm{Ld}$ & $0.001 \pm 0.00$ & 0.000 \\
\hline \multirow{2}{*}{ Affon } & Low-flow & $<\operatorname{Ld}$ & 0.000 & $<\mathrm{Ld}$ & $0.045 \pm 0.00$ \\
\hline & Flood & $<\mathrm{Ld}$ & $<\mathrm{Ld}$ & $<\mathrm{Ld}$ & 0.000 \\
\hline
\end{tabular}

$<\mathrm{Ld}$ : lower than limit of detection.

Egypt. J. Chem. 60, No. 6 (2017) 
TABLE 4. Classification of water quality in the Ouémé basin for aquatic life.

\begin{tabular}{llcc}
\hline Stations & Rivers & WQI & Quality status \\
\hline Agonlin-Lowé & Ouémé River & 55.2 & Marginal \\
Bonou & Ouémé River & 62.7 & Marginal \\
Zagnanado & Ouémé River & 56.7 & Marginal \\
Toué & Zou River & 80.9 & Good \\
Atchérigbé & Zou River & 71.8 & Moderate \\
Dassa & Ouémé River & 65.7 & Moderate \\
Atchapka-Bethel & Ouémé River & 71.7 & Moderate \\
Atchakpa-Rejet & Ouémé River & 57.5 & Marginal \\
Atchakpa-Pompe & Ouémé River & 71.1 & Moderate \\
Kaboua & Opkara River & 52.7 & Marginal \\
Vossa & Beffa River & 64.3 & Marginal \\
Kpassa & Okpara River & 79.2 & Moderate \\
Bétérou & Ouémé River & 78.4 & Moderate \\
Affon & Ouémé River & 70.4 & Moderate \\
Donga & Donga River & 69.9 & Moderate \\
\hline
\end{tabular}

\section{Discussion}

The present study showed variations in the spatio-temporal profile of the environmental parameters. This allows characterization of the water in different levels of pollution.

Water temperature in the basin ranged from $26^{\circ} \mathrm{C}$ to $29^{\circ} \mathrm{C}$ without spatially- or seasonallysignificant variation. The observed water temperature range is characteristic of tropical environments and confirms those reported in other researchs about the Azili and Hlan lakes in the Republic of Benin [14, 15]. These high water temperatures might increase the toxicity of such substances as ionized ammonia. In fact, ionized ammonia becomes the predominant form of ammonia in surface water when temperature is high $\left(\geq 25^{\circ} \mathrm{C}\right)[16,17]$. But this reaction also depends on the water's $\mathrm{pH}$. Less than $10 \%$ of ammonia is in the toxic form when $\mathrm{pH} \leq 8.0$ and this increases dramatically as the $\mathrm{pH}$ increases [16]. Recorded $\mathrm{pH}$ in the Ouémé basin ranged from 6.4 to 9.8 with significant variations between stations $(p<0.05)$ as well as between hydrological seasons. Values greater than 8.0 are scarce and were recorded at the Kaboua, Vossa, Atchakpa-Rejet, and Agonlin-lowé stations in February and March. So, ionized ammonia (not evaluated in this study) might be generally low in the Ouémé basin. Dupont [18] has reported that
$\mathrm{pH}$ limits of the first biological damage are 5.5 and 8.5. This range is corroborated by Maïga et al. [19] who have set biological damage $\mathrm{pH}$ limits between 6.5 and 8.5. In the present study, this range is exceeded particularly during low flows at Kaboua and Vossa stations. This parameter being very correlated with most of biological parameters, it would then have an impact on the biological community in this environment during low flows [20].

Electrical conductivity is a factor which correlates with dissolved ions in water. It is a measure of total dissolved salts and an indicator of the level of mineralization of the water [21,22]. In the Ouémé basin, recorded conductivity ranged from $500 \mu \mathrm{S} . \mathrm{cm}^{-1}$ (Zagnanado) to $4700 \mu \mathrm{S} . \mathrm{cm}^{-1}$ (Kaboua). Significant variations were observed both spatially and seasonally $(\mathrm{p}<0.05$ ). Most times, values are located in the recommended range for aquatic life $\left(50-1500 \mu \mathrm{S} . \mathrm{cm}^{-1}\right)$ [23]. Sites such as Agonlin-lowé, Atchakpa-Rejet, and Kaboua had high conductance, above 2000 $\mu \mathrm{S} . \mathrm{cm}^{-1}$ during low flow. This is a result of high anthropogenic impacts including household, agriculture, and industrial activity at these stations. Decrease in water quantity during low flow increases the concentration of dissolved salts. These high values of electrical conductivity might damage aquatic life [17]. As far as Total 
Dissolved Solids (TDS) are concerned, recorded values range from $37 \mathrm{mg}$. $\mathrm{L}^{-1}$ (Zagnanado) to 335 mg. $L^{-1}$ (Kaboua). Means are significantly different both between stations and hydrological seasons ( $p$ $<0.05)$. According to Sibanda et al. [17], TDS is the sum total of all of the dissolved substances in water and includes hardness, alkalinity, chlorides, bromides, sulphates, silicates, and all manner of organic compounds. So, high TDS concentrations might cause aesthetic or nuisance problems. Benham et al. [24] reported that high TDS concentrations may indicate existence of potentially harmful contaminants such as metals and other agricultural or industrial chemicals. But the recorded TDS values in this study fall within the quality guidelines for domestic uses ( 0 to 450 mg.L-1) (DWAF, [17].

Dissolved oxygen is one of the important factors for aquatic life. It is one of the factors that can discriminate in the quality of surface water. Wetzel \& Likens [25] report that in a river, $\mathrm{O}_{2}$ is an indicator of water quality and organic pollution. This is a critical parameter for the survival of aquatic organisms [20]. The values observed during this study range from $2.1 \mathrm{mg}$.L${ }^{1}$ to $7.1 \mathrm{mg} . \mathrm{L}^{-1}$ with significant variations only between seasons $(p<0.05)$. The annual means of all sampling sites appear to be higher than the critical threshold of $4 \mathrm{mg} . \mathrm{L}^{-1}$ below which life of the aerobic microorganisms is affected [26]. Also, means during low flows and floods are higher than the latter standard. So, except low concentration values $\left(<4 \mathrm{mg} . \mathrm{L}^{-1}\right)$ in sites such as Agonlin-lowé, Bonou, Atchérigbé, Kaboua, and Vossa during the lowest flow (February to March), dissolved oxygen is not critical for aquatic life. The low concentrations recorded in these stations are the result of algal bloom as by Echornia crassipes proliferation and decomposition during low flow.

Alkalinity recorded at different stations on the Ouémé River range between $49.83 \mathrm{mg} . \mathrm{L}^{-}$ 1 and 329.99 mg. $\mathrm{L}^{-1}$. No significant difference was observed in the means between stations nor between seasons $(p>0.05)$. Annual means at sampling stations vary from $82.54 \mathrm{mg}$. $\mathrm{L}^{-1}$ to 149.9 mg. $\mathrm{L}^{-1}$. These values show high mineralization of the water which contains sufficient $\mathrm{CO}_{2}$ to allow the development of plankton [27]. For domestic use, water with alkalinity at less than $200 \mathrm{mg} . \mathrm{L}^{-1}$ is desirable, since the water is no more palatable beyond this limit [28]. Except the water at stations such as Affon, Atchakpa-Pumping, Dassa, Donga, Kpassa and Zagnanado during low flow, the alkalinity in all the other sites fall beneath this standard for human use. Since alkalinity is highly favored by $\mathrm{HCO}_{3}^{-}$which arises from $\mathrm{CO}_{2}$ dissolution [29] and mainly from limestone dissolution [30], the substrate in the latter stations during low flow may be responsible for the high alkalinity values recorded. High use of detergent by local inhabitants can also contribute to this high alkalinity. As for total hardness, recorded values are most of time below $60 \mathrm{mg} . \mathrm{L}^{-1}$, which is characteristic of freshwater [31]. In stations such as Atchakpa-Béthel, Atchakpa-Rejet, and Kaboua, hardness higher than $60 \mathrm{mg} . \mathrm{L}^{-1}$ with a maximum of $123 \mathrm{mg} . \mathrm{L}^{-1}$ (Kaboua) was observed during low flow. This results in high significance difference for hardness values between hydrological seasons in the Ouémé River basin. In Atchakpa-Bethel and Atchakpa-Rejet, the high hardness of the water may be due to sewage from the sugar plant which releases high amounts of magnesium and calcium into the water. At Kaboua, the high hardness may be the result of mineral solubilisation of the geological substratum and human releases into water. These observed high hardness values would have a mitigating effect on toxicity of the dissolved heavy metals [32].

Ammonium $\left(\mathrm{NH}_{4}^{+}\right)$is an incomplete form of the nitrification of organic nitrogen [33]. Its presence in high concentration is indicator of organic matter in the area. The recorded concentrations were between $0.02 \mathrm{mg} . \mathrm{L}^{-1}$ and $29.51 \mathrm{mg} . \mathrm{L}^{-1}$ with means between $0.3 \mathrm{mg} . \mathrm{L}^{-1}$ (Kpassa) and $5.57 \mathrm{mg} . \mathrm{L}^{-1}$ (Agonlin-lowé). No significant difference was observed both between site and season $(\mathrm{p}>0.05)$. The maximum concentration recorded (29.51 mg. $\left.\mathrm{L}^{-1}\right)$ most likely comes from a particular pollution point located in Agonlin-lowé in March. This pollution may come from household and releases from the Azowlissè market. Apart from this high concentration, a maximum of $9.74 \mathrm{mg} . \mathrm{L}^{-1}$ was recorded at Kaboua. According to Rodier [34], ammonium concentration in stream decreases from upstream to downstream. The results of this study show an irregular profile in the Ouémé basin. So, there must be a source of organic matter pollution in various areas of the basin. This may come from agriculture (which take place across the entire basin), household (existence of many urbanized areas), and/or industry (the sugar plant).

The recorded nitrite concentrations in the Ouémé basin vary from 0.0 to $1.83 \mathrm{mg} . \mathrm{L}^{-1}$, while the standard for aquatic organisms is $0.1 \mathrm{mg} . \mathrm{L}^{-1}$ [35]. 
The high concentration $\left(>0.1 \mathrm{mg} . \mathrm{L}^{-1}\right)$ observed at many of sampling stations particularly during low flows could affect the organisms. The observed concentration vary significantly both seasonally and spatially $(\mathrm{p}<0.05)$. High concentrations are recorded at Agonlin-lowé, Atchakpa-Rejet, Kaboua, and Vossa. Some recorded concentrations at Kaboua and Vossa during low flows are higher than the chronic standard of $0.2 \mathrm{mg} . \mathrm{L}^{-1}$ for human consumption [36] and reach $1 \mathrm{mg} \cdot \mathrm{L}^{-1}$ and 1.83 mg. $\mathrm{L}^{-1}$, respectively. These values confirm the high organic pollution in the Ouémé basin. Nitrates are the final biological oxidation product of all forms of nitrogen (organic nitrogen, ammonia, nitrite, etc.) [37]. Its sources are numerous. It could come from the atmosphere [38] or from the leaching of soils during rainfall. Anthropogenic release including nitrogen fertilizer use on crops are found to be the main source of contamination [39, 40]. The observed concentrations at the various stations of the present study, which are above 2 to $3 \mathrm{mg} . \mathrm{L}^{-1}$, are considered normal for surface waters $[41,42]$. It is the result of high organic loads in the basin (since concentrations are frequently greater than $10 \mathrm{mg} . \mathrm{L}^{-1}$ and reach $163 \mathrm{mg} . \mathrm{L}^{-1}$ at Kaboua and Vossa in the month of March). Nitrate in high concentrations promotes plant growth which can be disastrous for the aquatic ecosystem when plant proliferation is pushed to excess (eutrophication) [39]. The high concentrations observed during low flows at stations such as Atchakpa-Rejet, Kaboua, Vossa, and Agonlin-lowé have induced the observed high algal and plant proliferation which can affect ecosystem function.

Orthophosphate concentrations recorded in the study vary between $0.03 \mathrm{mg} . \mathrm{L}^{-1}$ and $4.2 \mathrm{mg} . \mathrm{L}^{-}$ ${ }^{1}$. This presents a significant variation throughout sampling stations and over seasons $(p<0.05)$. This difference comes from the high concentrations observed at Kaboua (maximum of $2.39 \mathrm{mg} . \mathrm{L}^{-1}$ ) and at Vossa (maximum of $4.2 \mathrm{mg} . \mathrm{L}^{-1}$ ) during low flows. Rodier [41] estimates that orthophosphate concentrations greater than $0.5 \mathrm{mg} \cdot \mathrm{L}^{-1}$ should constitute a pollution index. Seen as such, the high recorded concentrations can damage the ecosystem's functions. Orthophosphate is the major cause of eutrophication in freshwater systems [29]. Its sources are mostly from anthropogenic activities. Natural inputs are related to the leaching of some rocks (igneous or sedimentary). As a result, in the absence of anthropogenic inputs, surface water contains very little phosphates [39]. This demonstrates the importance of human impacts on the ecosystem of the Ouémé River basin.
By clustering the sampled stations on the basis of physico-chemical parameters, it was noticed that Atchakpa-Rejet and Kaboua are characterized by parameters such as nitrite, nitrate, ammonium, orthophosphate, conductivity, TDS, pH, calcium, magnesium, and total hardness. This explains the high concentration of these parameters in the wastewater from the sugar plant. Kaboua is impacted by fuels and by other human releases. It also receives pollutants from upstream. Kpassa, Bétérou, and Atchakpa-Bethel are characterized by high value of dissolved oxygen and high transparency. These three stations have a rocky substratum and emergent rocks which, in contact with the flowing water, can increase atmospheric oxygen dissolution and favor sedimentation of suspended particles. All other stations are characterized by high alkalinity, which shows the importance of this parameter for the basin. Only a few stations (Affon, Atchakpa-Pumping, Dassa, Donga and Zagnanado) have alkalinity higher than the standard (200 mg.L-1) for domestic uses [28] during low flow.

In the Ouémé River basin, dissolved metals such as cadmium, lead, copper, and zinc have been detected at concentrations that are often above the ecological quality standards of surface waters [43]. The recorded concentrations of cadmium range from undetectable to $0.012 \mathrm{mg} . \mathrm{L}^{-1}$. It was detected only at the Zagnanado, Dassa, and Kaboua stations. Higher concentrations were found during low flows. Cadmium is a unessential element and is highly toxic to freshwater organisms [44]. The mean concentrations observed at the three stations where it was detected are higher than the standard of $0.00015 \mathrm{mg} . \mathrm{L}^{-1}$ recommended for protection of aquatic life [44]. The concentration at Kaboua was also higher than the $0.003 \mathrm{mg} . \mathrm{L}^{-1}$ recommended for domestic use and drinking purposes [45]. On the basis of cadmium loads, water in the latter three stations during low flows is potentially harmful to both aquatic life and human health. The source of cadmium in the Ouémé River, particularly at the Zagnanado, Dassa, and Kaboua stations could be fertilizers and transportation and use of fuels (petrol) around these sites.

Lead is both an unessential and toxic metal with no nutritional value for living organisms [44]. The observed concentrations are between undetectable and $0.4 \mathrm{mg} . \mathrm{L}^{-1}$. It was detected at most of the sampling stations except Toué, Atchérigbé, Vossa, and Donga. The recorded concentrations, particularly during low flows,

Egypt. J. Chem. 60, No. 6 (2017) 
were higher than the standard of $0.0002 \mathrm{mg} . \mathrm{L}^{-1}$ recommended for aquatic life. So this metal should not be present in any water meant for any kind of living organism. The observed concentrations are also usually higher than the standard of 0.01 mg. $L^{-1}$ recommended for human use [45]. Since lead toxicity is dependent of hardness, water in the Ouémé basin is therefore harmful (with hardness generally low).

Zinc and copper are two metals of biological importance. They become harmful only when their concentrations are high. Recorded zinc concentrations range from undetectable to 0.029 mg. $L^{-1}$. These concentrations usually exceed the guideline of $0.002 \mathrm{mg} . \mathrm{L}^{-1}$ recommended for aquatic life [44]. Recorded copper concentrations range from undetectable to $0.057 \mathrm{mg} . \mathrm{L}^{-1}$ and are usually higher than the standard of $0.0003 \mathrm{mg} . \mathrm{L}^{-}$ ${ }^{1}$ recommended for aquatic life protection. Crop fertilizers, pesticides, herbicides and fuels are main sources of zinc and copper in Ouémé River basin.

In terms of metal $(\mathrm{Cd}, \mathrm{Pb}, \mathrm{Zn}, \mathrm{Cu})$ contamination of water in the Ouémé basin, the water is harmful to both aquatic life and human health.

The water quality index calculation allowed identifying three quality categories for aquatic life. CCME-WQI values ranged from 52.7 to 80.9, classifying water quality to either good, moderately polluted, or marginal quality for aquatic life. On the basis of this, good quality water was observed only at the Toué station, which is not impacted by (or is little impacted by) human activities. Moderately polluted water is founded at such stations as Atchérigbé, Dassa, Atchapka-Bethel, Atchakpa-Pumping, Kpassa, Bétérou, Affon, and Donga. Each of these stations is directly polluted by both household and agricultural effluents; exception being to the Atchakpa-Bethel stations whose pollution comes mainly from the wastewater released by the sugar plant. As for marginal quality of water, this one was observed at stations such as Agonlin-lowé, Bonou, Zagnanado, AtchakpaRejet, Kaboua and Vossa. The first three stations are located in the downstream portion of the basin and are a receptacle for all the suspended particles collected from upstream. These stations are also highly urbanized and agriculture is developed. So, agriculture and urbanization are pollution sources that can explained the bad chemical quality of this water for aquatic life. Atchakpa-Rejet is the site directly receiving wastewater from the sugar plant. The probably low efficiency of the water treatment system of this plant [7] explains the high load of the chemical parameters at the station. Regarding the Kaboua station, located at downstream of the Okpara River, it is a receptacle for all the pollution that comes from upstream. This station is also highly impacted by human activities, being a forest site of unlawful exchange between the Republic of Benin and the Federal Republic of Nigeria. Road transportation of fuels is highly developed and roads accidents do occur, sometimes releasing important quantities of lost fuel onto the ground. This can wash away into the river system. The river is therefore usually receiving these fuel-originated contaminants which become concentrated during low flow. The Vossa station appears to be highly polluted during low flows, since it is in downstream of the Beffa River. This river collects all the released pollutants in the Ouessè area. Agricultural production is also an important source of pollution in this river.

\section{Conclusion and Recommendations}

This study has shown that the water in the Ouémé river basin is highly mineralized. The reduction in water quantity during low flow periods contributes to the increase in this mineral load. The high mineral loads at stations such as Kaboua, Agonlin-lowé, Vossa, and AtchakpaRejet facilitate eutrophication of those portions of the river. The concentration of dissolved metals such as cadmium, lead, copper, and zinc exceeds the ecological quality standards at most of the sites in which they were detected. Wastewater from the SUCOBE sugar plant highly impacts the quality of the Ouémé River ecosystem. In all, water in the Ouémé basin is of poor quality for aquatic life and also of poor quality for humans.

It is recommended the construction of waste water treatment plant in all urbanized areas in the Ouémé River Basin. The SUCOBE Company, which already has a treatment plant, must review its efficiency to reduce the pollution induced in the basin. Also the promotion of organic agriculture in the basin should improve the quality of releases.

\section{Acknowledgement}

We are grateful to the West Africa Agricultural Productivity Program (WAAPP) which funded this research. We thank all those who have contributed in one way or another to this study. We also thank the reviewers for their comments and contributions. 


\section{References}

1. Bharti N. and Katyal D., Water quality indices used for surface water vulnerability assessment. International Journal of Environmental Sciences, 2(1), 154-173 (2011).

2. Bouthir F.Z., Chafik,A., Benbrahim S., Souabi S., El Merdhy H., Messoudi A. and Sifeddine M., Mytilus galloprovincialis comme indicateur de la contamination métallique. Marine Life, 14(1-2), 59-70 (2004).

3. Nassali H., Bouih H., Srhiri A. and Dhahbi M., Influence des rejets des eaux usées sur la composition des eaux de surface et des sédiments superficiels du lac Merja Fouarate au Maroc. Afrique Science, 1(1), 145-165 (2005).

4. Bricha S., Ounine K., Oulkheir S., EL Haloui N. and Attarassi B., Étude de la qualité physico-chimique et bactériologique de la nappe phréatique M'nasra, Maroc. Afrique Science. 3(3), 391-404 (2007).

5. Foussard V. and Etcheber H., Proposition d'une stratégie de surveillance des paramètres physico-chimiques pour les estuaires de la Seine, de la Loire et de la Gironde. Projet LITEAU-BEEST. 75 p (2011).

6. Mustapha M.K., Assessment of the water quality of Oyun Reservoir, Offa, Nigeria, using selected physico-chemical parameters. Turkish Journal of Fisheries and Aquatic Sciences, 8, 309-319 (2008).

7. Houssou A.M., Houeto G.T.K. and Montchowui E., Qualité de l'eau et distribution du zooplancton dans le complexe Fleuve Ouémé - système d'épuration d'eau usée de la SUCOBE au Bénin. Livre des résumés. Journées Scientifiques Internationales de Lomé, XVIIè Edition, du 3 au 8 octobre 2016. Page 212 (2016a).

8. Kumar S. and Managi S., The economics of sustainable development: The case of India. Springer Science \& Business Media. 296p (2009).

9. Richards S., Paterson E., Withers P.J. and Stutter M., The contribution of household chemicals to environmental discharges via effluents: combining chemical and behavioural data. Journal of Environmental Management. 150, 427-434 (2015).

10. Boko M., Saisons et types de temps au Bénin: analyse objective et perceptions populaires. Espace géographique. 21(4), 321-332 (1992).

11. MAEP (Ministère de l'Agriculture de l'Elevage et de la Pêche), Rapport national sur l'état des ressources phytogénétiques pour l'alimentation et l'agriculture. 57p (2007).

12. APHA (American Public Health Association)., StanA dard methods for examination of water and wastewater, $21^{\text {st }} \mathrm{ed}$. APHA, AWWA, WPCF, Washington
DC, USA. (2005).

13. Ahouansou Montcho S., Diversité et exploitation des poissons de la rivière Pendjari (Bénin, Afrique de l'Ouest). Thèse de Doctorat, Université d'Abomey-Calavi, Bénin. 201 p (2011).

14. Houssou A.M., Agadjihouédé H., Montchowui E., Bonou C.A. and Laleye P., Structure and seae sonal dynamics of phytoplankton and zooplankton in Lake Azili, small Lake of the pond of River Ouémé,"Benin". International Journal of Aquatic Biology. 3(3), 161-171 (2015).

15. Houssou A.M., Agadjihouédé H., Bonou C.A. and Montchowui E., Composition and seasonal variation of phytoplankton community in Lake Hlan, Ouémé River basin, Republic of Benin. International Journal of Aquatic Biology. 4(6), 378-386 (2016b).

16. Hargreaves J.A. and Tucker C.S., Managing am» monia in fish ponds. Southern regional aquaculture center. Retrieved June 03, 2017, from https://srac. tamu.edu/index.cfm/event/getFactSheet/whichfactsheet/169. (2004).

17. Sibanda T., Chigor V.N., Koba S., Obi C.L. and Okoh A.I., Characterization of the physicochemił cal qualities of a typical rural-based river: ecological and public health implications. International Journal of Environmental Science and Technology. 11,1771-1780 (2014).

18. Dupont J., La problématique des lacs acides au Québec. Direction du suivi de l'état de l'environnement, Ministère de l'Environnement, Envirodoq no ENV/2004/0151, collection no QE/145, 18 p. (2004).

19. Maiga A.H., Konate Y., Wethe J., Denyigba K., Zoungrana D. and Togola L., Performances épuratoires d'une filière de trois étages de bassins de lagunage à microphytes sous climat sahélien: cas de la station de traitement des eaux usées de l'EIER. Sud Sciences et Technologies, 14, 1-9 (2006).

20. Fakayode S.O., Impact assessment of industrial eft fluent on water quality of the receiving ALaro River in Ibadan, Nigeria. Ajeam-Ragee. 10, 1-13 (2005).

21. Chang H., Spatial analysis of water quality trends in the Han River basin, South Korea. Water Research. 42, 3285-3304 (2008).

22. N'Diaye A.D., Mint Mohamed Salem K. and Ould Sid'Ahmed Ould Kankou M., Contribution à l'étude de la qualité physicochimiques de l'eau de la rive droite du fleuve Sénégal. Larhyss Journal. 12, 71-83 (2013).

23. IBGE (Institut Bruxellois pour la Gestion de l'Environnement), Qualité physico-chimique et chimique

Egypt. J. Chem. 60, No. 6 (2017) 
des eaux de surface: cadre général. 16p (2005).

24. Benham B., Ling E.J., Wright B. and Haering K., Virginia Household Water Quality Program: Total Dissolved Solids (TDS) in Household Water. Communications and Marketing, College of Agriculture and Life Sciences, Virginia Polytechnic Institute and State. Virginia University Publication. 442-666 (2011).

25. Wetzel R.G. and Likens G.E., Limnological analysis. $3^{\text {rd }}$ ed. Springer-Verlag, New York, 391p (2006).

26. Cornaz S., Evaluation du statut trophique d'un canal de drainage sous l'impact des pollutions d'origines diffuses et ponctuelles: Le cas du Grand Canal de la plaine du Rhône. Ed. Université, IGUL Institut de géographie. 180p (2004).

27. Ekelemu J.K. and Zelibe S.A.A., Growth patterns and condition factors of four dominant fish species in Ona Lake, Southern Nigeria. Journal of Fisheries International. 1(2-4), 157-162. (2006).

28. BIS (Bureau of Indian Standards) IS 14543, PackB aged Drinking Water (Other than Packaged Natural Mineral Water) [FAD 14: Drinks and Carbonated Beverages], with latest amendments. 37p (2004).

29. Radojević M. and Bashkin V.N., Practical Environmental Analysis, 2è ed. Royal Society of Chemistry, Cambridge, 458p (2006).

30. Boyd C.E., Water Quality: An Introduction. Kluwer Academic Publisher. 330p (2000)

31. Khound N.J., Phukon P. and Bhattacharyya K.G., Physico-chemical studies on surface water quality in the Jia-Bharali River Basin, India [Electronic version]. Archives of Applied Science Research 4(2),1169-1174. (2012).

32. Wilson C.P., Water quality notes: Alkalinity and Hardness; University of Florida IFAS Extension: Publication No. SL 332. Retrieved June 03, 2017, from www.edis.ifas. ufl.edu/topic_series_water quality_notes. (2010).

33. Abai E.A., Ombolo A., Ngassoum M.B. and Mbawala A., Monitoring of the physico-chemical and bacteriological quality of the Ngaoundéré rivers waters, Cameroon. Revue Internationale des Sciences et Technologie, 10(4), 135-145 (2014).

34. Rodier J., Bazin C., Broutin J.P., Chambon P., Champsaur H. Rodi L., L'analyse de l'eau, eaux naturelles, eaux résiduaires, eau de mer, chimie, physico-chimie, microbiologie, biologie, interprétation des résultats. Ed. Dunod, Paris, 1384 p. (2005).

35. Morin R., «Qualité de l'eau requise pour l'élevage des salmonidés». Document d'information DADD14. Ministère de l'Agriculture, des Pêcheries et de l'Alimentation. http://www.mapaq.gouv.qc.ca/Fr/ Peche. 25p (2012).

Egypt. J. Chem. 60, No. 6 (2017)
36. WHO (World Health Organisation), Guideline for Drinking Water Quality. Geneva. (1995).

37. Rajasegar M., Physico-chemical characteristics of the Vellar estuary in relation to shrimp farming. Journal of Environmental Biology, 24, 95-101. (2003).

38. Ramade F., Elements Of Ecology: Applied Ecology. Paris: Dunod, 864 p (2005).

39. Banas D. and Lata J., Nitrates. In: The White Paper Pollutants Habitat. 10p (2006).

40. Khalaf H.A., Mekhemer G.A.H., Nohman A.K. and Mansour S.A.A., Phosphated alumina catalysts: surface properties and reactivity towards $2-\mathrm{PrOH}$ decomposition. Monatshefte Fur Chemie. 138, 641p (2007).

41. Rodier J., Bazin C., Broutin J.P., Chambon P., Champsaur H. and Rodi L., L'analyse de l'eau, 8è édition. Dunod (Éditeur), Paris, France. (1996).

42. Rodier J., L'analyse de l'eau (Eaux Naturelles, Eaux Résiduaires Et Eaux De Mer), 8eme édition, Ed. Dunod. Paris, 1383p (2009).

43. MEEM (Ministère français de l'Environnement, de l'Énergie et de la Mer), Guide technique Relatif à l'évaluation de l'état des eaux de surface continentales (cours d'eau, canaux, plans d'eau). Directive 2000/60/CE, 106p (2016).

44. Edokpayi J.N., Odiyo J.O., Popoola O.E. and MsaA gatin T.A., Assessment of trace metals contaminas tion of surface water and sediment: A case study of Mvudi River, South Africa. Sustainability. 8(2), 135. (2016).

45. WHO (World Health Organisation), Guidelines for Drinking-Water Quality, $4^{\text {th }}$ ed.; WHO: Geneva, Switzerland, pp 155-202 (2011).

46. CCME (Canadian Council of Ministers of the Envin ronment), Canadian Environmental Quality Guidei lines Water Quality Index Technical report and user's manual, Gatineau, QC, Canada. (2001).

(Received 9/8/2017; accepted 23/11/2017) 